\title{
Kemampuan literasi informasi peneliti dalam penulisan karya ilmiah di Loka Litbangkes Pangandaran
}

\author{
Dani Arif Cahyadi \\ Sekolah Pascasarjana Universitas Gadjah Mada \\ Jl. Teknika Utara, Pogung, Mlati, Sleman, Yogyakarta 55281 \\ E-mail: dani.arif.c@mail.ugm.ac.id
}

Received: July 2018; Accepted: December 2018; Published: December 2018

\begin{abstract}
The productivity of scientific papers in disseminating research results, mastering basic tasks and competencies in functional positions does not necessarily make the researcher a literate person. Researchers at the Loka Litbangkes, Pangandaran still indicated the existence of issues related to the mastery of information literacy especially in writing scientific papers. The information literacy capabilities of researchers are not yet known comprehensively and deeply, so research is needed to uncover it. This study used a descriptive qualitative approach. The purpose of the study was to obtain a clear picture of the information literacy abilities of researchers, especially in scientific writing. The conceptual research framework to study the information literacy skills of researchers used the SCONUL Seven Pillars Information Literacy Research Lens. Informants were three researchers and colleagues at the Loka Litbangkes, Pangandaran who were determined based on purposive sampling. Results showed that researchers did not master information literacy skills yet. First-level researchers indicated that they did not fully master the Plan, Gather and Evaluate competencies. Middle-level researchers were indicated that they did not master the competencies of Plan, Gather, Evaluate and Present. Whereas the high-level researchers were indicated that they did not fully master the Plan, Gather, Evaluate, Manage and Present competencies. In conclusion, the researcher's information literacy skills are constrained by the lack of participation in information literacy training, limitations and irregularities in library collections, unavailability of access to Scopus indexed international journal databases, lack of science communication networks motivations and limited English proficiency.
\end{abstract}

Keywords: Information literacy; Scientific writing; Researcher; Sconul seven pillars information literacy

\begin{abstract}
Abstrak
Produktifitas karya tulis ilmiah dalam diseminasi hasil penelitian, penguasaan tugas pokok dan kompetensi jenjang jabatan fungsional belum tentu menjadikan peneliti sebagai literate person. Peneliti di Loka Litbangkes Pangandaran masih mengindikasikan adanya isu terkait dengan penguasaan literasi informasi khususnya dalam penulisan karya ilmiah. Kemampuan literasi informasi peneliti belum diketahui secara komprehensif dan mendalam sehingga diperlukan penelitian untuk dapat mengungkapnya. Penelitian ini menggunakan pendekatan kualitatif deskriptif. Tujuan penelitian untuk memperoleh gambaran jelas mengenai kemampuan literasi informasi peneliti khususnya dalam penulisan karya ilmiah. Kerangka konsep penelitian untuk mengkaji kemampuan literasi informasi peneliti menggunakan SCONUL Seven Pillars Information Literacy Research Lens. Informan penelitian terdiri dari tiga orang peneliti dan rekan sejawatnya di Loka Litbangkes Pangandaran yang ditentukan berdasarkan purposive sampling. Hasil penelitian menunjukan kemampuan literasi informasi belum sepenuhnya dikuasai oleh peneliti. Peneliti Tingkat Pertama terindikasi belum sepenuhnya menguasai kompetensi Plan, Gather dan Evaluate. Peneliti Tingkat Muda terindikasi belum menguasai kompetensi Plan, Gather, Evaluate dan Present. Peneliti Tingkat Madya terindikasi belum sepenuhnya menguasai Plan, Gather, Evaluate, Manage dan Present. Faktor yang menghambat kemampuan literasi informasi peneliti adalah kurangnya partisipasi dalam pelatihan literasi informasi, keterbatasan dan ketidakberkalaan koleksi pustaka di perpustakaan, akses database jurnal internasional terindeks Scopus belum tersedia, kurangnya motivasi peneliti dalam berjejaring komunikasi ilmiah dan keterbatasan peneliti dalam keterampilan menggunakan bahasa Inggris.
\end{abstract}

Kata kunci: Literasi informasi; Karya tulis ilmiah; Peneliti; Sconul seven pillars information literacy

doi: https://dx.doi.org/10.24198/jkip.v6i2.17774

(C) 2018 Jurnal Kajian Informasi \& Perpustakaan. This is an open access article under the CC BY-SA license

Website: http://jurnal.unpad.ac.id/jkip 


\section{PENDAHULUAN}

Dewasa ini seiring dengan perkembangan ilmu pengetahuan dan teknologi, literasi informasi diterapkan dalam ruang lingkup yang lebih luas. Kemampuan literasi informasi telah terbukti menunjang profesonalisme pustakawan di perpustakaan perguruan tinggi (Sukaesih \& Rohman, 2013). Kemampuan literasi informasi juga telah membantu aktifitas kerja para teknisi di perusahaan swasta sektor minyak dan telekomunikasi di Kuwait (Chaudhry \& Al-Mahmud, 2015), serta menjadi kunci kesuksesan di lingkungan kerja dan aktifitas sehari-hari serta penting di era informasi yang berlimpah saat ini (Wicaksono, 2016; Cheuk, 2008). Literasi informasi merupakan kemampuan teknis seseorang atau masyarakat atas informasi secara lebih fungsional (Yusup \& Saepudin, 2017). Praktik pemberdayaan informasi misalnya menulis blog mengenai isu-isu yang sedang menjadi perbincangan masyarakat, menulis paper untuk memperoleh angka kredit, dan sebagainya.

Kemampuan literasi informasi memiliki kaitan erat dengan keterampilan menulis ilmiah. Seseorang yang telah literat dalam menulis karya ilmiah akan memiliki kemampuan untuk mengenali kebutuhan informasi, mengetahui keberadaan informasi, memperlakukan informasi dengan etis, menilai informasi dan menciptakan pengetahuan baru dari suatu informasi (Bordonaro, 2008). Peningkatan kemampuan literasi informasi terbukti membantu kemampuan menulis misalnya dalam penggunaan operator boolean, identifikasi manfaat sumber informasi dan pemahaman gaya sitasi (White-Farnham \& Gardner, 2014). Kemampuan literasi informasi dapat meningkat jika seseorang telah memiliki terlebih dahulu kemampuan untuk menelusur informasi, menggunakan metodologi, menulis essai, berpikir kritis dan bersikap ilmiah (Soleymani, 2014). Individu dengan karakteristik berpikir kritis dan logis memiliki kemampuan menganalisis, mensintesa, mengevaluasi dan menalar agar tidak mudah diperdaya oleh informasi yang diterimanya (Hasugian, 2008). Oleh karenanya untuk menguasai literasi informasi seseorang harus terampil terlebih dahulu dalam menulis ilmiah dengan mentaati metodologi dan memiliki kemampuan berpikir kritis. Selain kedua aspek tersebut, seseorang yang literat dalam penulisan karya ilmiah harus bersikap etis dan legal dalam menelusur dan menggunakan informasi misalnya kemampuan untuk mengutip sumber informasi secara tepat dalam menulis ilmiah (Rapchak \& Cipri, 2015). Kutipan dikenal juga dengan istilah sitasi. Sitasi merupakan etika yang menjadi ramburambu dalam proses penulisan karya ilmiah. Sumber informasi yang dicantumkan dengan tepat melalui sitasi merupakan sikap etis dan legal dalam penulisan karya tulis. Hubungan lainnya yaitu kemampuan literasi informasi yang didalamnya terdapat kemampuan berpikir kritis disinyalir dapat membantu meningkatkan kompetensi menulis ilmiah dan prestasi akademik (Shao \& Purpur, 2016). Penguasaan literasi informasi juga mempunyai pengaruh yang signifikan terhadap produktifitas dalam organisasi (Detlor, Julien, Willson, Serenko \& Lavallee, 2011; Cheuk, 2008)

Berdasarkan Peraturan Kepala LIPI Nomor 04/E/2012, karya tulis ilmiah merupakan tulisan hasil litbang dan/atau tinjauan, ulasan (reviu), kajian dan 
pemikiran sistematis yang dituangkan oleh seseorang atau kelompok yang memenuhi kaidah ilmiah (LIPI, 2012). Karya tulis ilmiah merupakan tolok ukur kinerja peneliti sesuai dengan Pedoman Jabatan Fugsional Peneliti. Sesuai dengan Keputusan Menteri Pendayagunaan Aparatur Negara Nomor: KEP/128/M.PAN/9/2004 seluruh jenjang fungsional peneliti mulai dari pertama, muda, madya sampai utama mensyaratkan penyusunan karya tulis ilmiah hasil penelitian dan mengembangkannya sesuai dengan bidang penelitian dengan memperhatikan isu-isu nasional dan internasional dan kebutuhan pasar yang mendukung pembangunan berkelanjutan (Menteri Pendayagunaan Aparatur Negara, 2004).

Penulisan karya ilmiah yang merupakan salah satu kegiatan diseminasi penelitian di Loka Penelitian dan Pengembangan Pengendalian Penyakit Bersumber Binatang (Litbangkes), Kementerian Kesehatan, Pangandaran. Karya tulis ilmiah terdiri dari buku, artikel, manuskrip, permodelan terkait hak atas kekayaan intelektual (HAKI) dan sebagainya. Karya tulis ilmiah mengkaji hasil penelitian yang menjadi rekomendasi bagi program pemerintah dan pengetahuan untuk menunjang pola hidup masyarakat.

Kemampuan peneliti dalam menulis karya ilmiah seharusnya berbanding lurus dengan penguasaan literasi informasi. Karya tulis ilmiah dihasilkan oleh tahapan sistematis yang sesuai dengan kaidah ilmiah. Setiap tahapan penulisan mengindikasikan interaksi dengan informasi. Dengan demikian penulisan karya ilmiah membutuhkan kemampuan mengolah mengumpulkan, menilai dan menggunakan informasi. Literasi informasi mencakup kemampuan berpikir kritis, bersikap ilmiah dan etis sebagaimana tuntutan dasar kompetensi sebagai peneliti.

Berdasarkan observasi masih terdapat indikasi isu dalam penguasaan literasi informasi dalam penulisan karya ilmiah dan etika penelusuran informasi. Penelitian yang mengkaji kemampuan literasi informasi peneliti belum pernah dilakukan di Loka Litbangkes Pangandaran sehingga tidak diketahui kemampuan mereka dalam menemukan, mengorganisasi, mengevaluasi dan menggunakan informasi secara efektif, efisien, dan etis khususnya dalam penulisan karya ilmiah. Pengetahuan mengenai kemampuan literasi penting untuk dikaji secara mendalam karena pada saat bersamaan mereka aktif dalam kegiatan diseminasi hasil penelitian dan pengembangan kesehatan melalui penulisan karya ilmiah. Upaya tersebut dalam kacamata kajian ilmu perpustakaan dan informasi merupakan gerakan literasi informasi di bidang kesehatan.

Berdasarkan latar belakang masalah, perumusan masalah dalam penelitian adalah kemampuan literasi informasi peneliti dalam penulisan karya ilmiah beserta faktor-faktor pendukung dan penghambatnya di Loka Litbangkes Pangandaran belum diketahui secara ilmiah dan komprehensif sehingga diperlukan penelitian untuk menjawab masalah tersebut. Pertanyaan penelitian terdiri dari, (1) Bagaimana penguasaan literasi informasi peneliti pertama, muda dan madya dalam penulisan karya ilmiah di Loka Litbangkes Pangandaran, (2) Faktor apa saja yang mendukung dan menghambat penguasaan literasi informasi peneliti dalam penulisan karya ilmiah di Loka Litbangkes Pangadaran? 
Model literasi informasi yang cocok digunakan dalam penelitian ini adalah SCONUL Seven Pillars Information Literacy Research Lens. Pertimbangan penggunaan model ini adalah ruang lingkup literasi informasi dalam lingkup luas, fleksibilitas penguasaan literasi informasi dapat berjalan tidal linear dan simultan, perhatian khusus terhadap aspek legal dan etis dalam penggunaan dan digitalisasi informasi serta kemampuan berpikir kritis dan bersikap ilmiah seseorang khususnya dalam karya tulis.

Penelitian ini berusaha menggambarkan kemampuan literasi informasi peneliti dalam penulisan karya ilmiah di Loka Litbangkes Pangandaran secara mendalam. Hasil penelitian dapat menambah khasanah penerapan literasi informasi dalam lingkup luas sekaligus menjadi rekomendasi dalam pengembangan kompetensi sumber daya manusia khususnya dalam publikasi ilmiah.

\section{METODE PENELITIAN}

Penelitian menggunakan metode deskriptif agar mampu memberikan gambaran dan identifikasi yang lebih jelas tentang pola dan dinamika penguasaan literasi informasi dalam penulisan karya ilmiah. Keunikan setiap kartakteristik peneliti menjadi alasan digunakannya pendekatan kualitatif untuk menjelaskan pola interaksi peneliti dengan informasi. pendekatan menekankan peneliti sebagai informan dalam berinteraksi dan mengungkapkan permasalahan dengan informasi berdasarkan perspektifnya sendiri.

Model kerangka konsep penelitian menggunakan SCONUL Seven Pillars Information Literacy Research Lens untuk mengetahui penguasaan literasi informasi peneliti dalam penulisan karya ilmiah. Penguasaan literasi informasi berdasarkan model tersebut terdiri dari kompetensi Identify, Scope, Plan, Gather, Evaluate, Manage, dan Present (Bent \& Stubbings, 2011). Identify merupakan kemampuan mengetahui kebutuhan informasi untuk menjawab pertanyaan penelitian. Scope adalah kemampuan menilai pengetahuan yang dimiliki dan mengidentifikasi gap. Plan yaitu kemampuan untuk membangun strategi dalam menemukan loka sumber informasi dan data. Gather adalah kemampuan mengumpulkan dan mengakses sumber informasi dan data yang dibutuhkan. Evaluate adalah kemampuan mengulas, membandingkan, mengevaluasi dan merevisi data dan sumber informasi. Manage merupakan kemampuan mengorganisasi sumber informasi dan data secara profesional. Present adalah kemampuan mengaplikasikan pengetahuan melalui, presentasi, sintesis dan diseminasi karya tulis ilmiah.

Penelitian dilakukan di Loka Litbangkes Pangandaran berlamat di Jalan Raya Pangandaran Km. 3 Desa Babakan Kecamatan Pangandaran Kabupaten Pangandaran. Pelaksanaan penelitian dari tanggal 13 Agustus 2017 sampai dengan 31 Mei 2018. Loka Litbangkes Pangandaran merupakan satuan kerja Badan Penelitian dan Pengembangan Kesehatan, Kementerian Kesehatan. Subjek penelitian adalah peneliti yang telah memiliki jenjang fungsional di Loka Litbangkes Pangandaran. Jumlah peneliti di Loka Litbangkes 
Pangandaran sampai dengan Tahun 2018 adalah 21 orang.

Objek penelitian selanjutnya disebut informan penelitian ditentukan berdasarkan purposive sampling dengan kriteria sebagai berikut, (1) Jenjang fungsional dengan tingkat pertama, muda, dan madya di Loka Litbangkes Pangandaran, (2) Memiliki pengetahuan, pengalaman dan kekayaan informasi mengenai penelitian dan kegiatan diseminasi, (3) Masa kerja minimal selama 7 Tahun di Loka Litbangkes Pangadaran,

Pengalaman sebagai anggota dan pimpinan redaksi media publikasi ilmiah minimal selama 2 tahun, (5) Bersedia berpartisipasi sebagai informan penelitian.

Berdasarkan kriteria tersebut ditentukan informan sejumlah 3 peneliti terdiri dari Informan 1 (Peneliti pertama), Informan dua (Peneliti muda) dan Informan tiga (Peneliti Madya). Untuk keperluan keterangan tambahan dan verifikasi data, penulis melakukan wawancara dan observasi terhadap rekan sejawat dari setiap informan penelitian tersebut sejumlah 3 orang peneliti yang memiliki tingkat jenjang fungsional yang sama yaitu RS1, RS2 dan RS3.

Teknik pengumpulan data menggunakan studi pustaka dengan memeriksa dokumen milik informan yang terkait dengan penulisan karya ilmiah. Wawancara semi terstruktur dengan mengajukan pertanyaaan terbuka yang sesuai dengan konteks literasi informasi dalam penulisan karya ilmiah. Observasi kegiatan informan dalam kegiatan yang berkaitan dengan penguasaan literasi informasi dan penulisan karya ilmiah.
Ibrahim (2015) menjelaskan analisis data menggunakan teknik interaktif. Menurutnya, tahapan penelitian terdiri dari penelahaan hasil wawancara, studi pustaka dan observasi informan. Selanjutnya data-data tersebut direduksi, diabstraksi dan dirangkum secara sistematis kemudian disusun dalam satuan-satuan informasi agar diperoleh deskripsi penguasaan literasi informasi peneliti. Reduksi ditujukan untuk menguji perolehan data dengan fokus penelitian. Tahap berikutnya menyajikan data dengan memastikan kesesesuaian dengan pertanyaan penelitian. Tahap terakhir yaitu menarik kesimpulan yang menjawab pertanyaan penelitian mengenai kemampuan literasi informasi peneliti dalam penulisan karya ilmiah beserta faktor-faktor pendukung dan penghambatnya.

Untuk memeriksa keabsahan data dilakukan triangulasi terhadap informan, rekan sejawat, tempat, waktu data diperoleh, dokumen terkait dan kajian literatur. Setiap data dan temuan yang dinilai belum jelas dilakukan verifikasi ulang kepada informan sampai dianggap memenuhi informasi yang dibutuhkan.

\section{HASIL DAN PEMBAHASAN}

Penelitian ini menggunakan SCONUL Seven Pillars Information Literacy Research Lens untuk mengkaji penguasaan literasi informasi peneliti dalam penulisan karya ilmiah. Berdasarkan temuan penelitian diketahui bahwa ketujuh kompetensi literasi tersebut belum dikuasai sepenuhnya oleh peneliti. Setiap peneliti mempunyai karakteristik yang berbedabeda dalam menguasai kemampuan literasi informasi. 
Informan satu, adalah peneliti dengan jenjang fungsional tingkat pertama di Loka Litbangkes Pangandaran. Informan 1 menguasai empat dari tujuh kompetensi literasi informasi SCONUL Seven Pillars Information Research Lens secara penuh terdiri dari identify, scope, manage dan present. Penguasaan Informan satu, terhadap kompetensi identify adalah sebagai berikut, (1) mengidentifikasi kebutuhan sumber informasi untuk penulisan karya ilmiah berdasarkan kesesuaian dengan tujuan dan tema, (2) menentukan pertanyaan penelitian melalui perumusan masalah yang tepat kemudian dijawab dengan tujuan penelitian dalam kesimpulan, membuat daftar kebutuhan informasi dalam penulisan karya tulis berdasarkan penilaian akreditasi dan indeks jurnal sebagai media publikasi.

Penguasaan informan satu dalam kompetensi scope meliputi, (1) menilai relevansi sumber informasi yang digunakan dalam karya tulis berdasarkan tema artikel, indeks dan akreditasi media publikasi, (2) menentukan gap dan kesenjangan dalam permusan masalah berdasarkan studi literatur dan pengamatan langsung fenomena di lapangan yang tidak sesuai dengan kajian teori, (3) memahami teknik pengumpulan data dalam penelitian meliputi wawancara baik terstruktur, semi terstruktur dan terbuka, observasi, eksperimen, dan forum group discussion.

Penguasaan informan satu dalam kompetensi manage meliputi, menggunakan perangkat lunak Mendeley untuk mengolah bibliografi dalam karya tulis, (2) menggunakan gaya sitasi Harvard dan Vancouver lebih sering dibanding lainya karena tuntuan gaya selingkung media publikasi dalam bidang kajian keilmuan Arbovirosis, (3) memahami berbagai macam bentuk plagiarisme dan pencegahannya dalam karya tulis ilmiah, (4) memahami etika dan hak cipta dalam menulis karya ilmiah.

Penguasaan informan satu dalam kompetensi present meliputi, memahami dan menerapkan ringkasan dan sintesis dalam karya tulis ilmiah, (2) menyajikan data dalam karya ilmiah dengan gaya penulisan yang baku dan sesuai dengan Kamus Besar Bahasa Indonesia, (3) menggunakan kegiatan diseminasi penelitian yang diselenggarakan Badan Litbangkes dan dinas terkait untuk mengkomunikasikan karya tulis ilmiah melalui presentasi oral dan poster, (4) menentukan media publikasi untuk menerbitkan karya tulis berdasarkan akreditasi untuk memperoleh angka kredit yang signifikan bagi peningkatan jenjang fungsional sebagai peneliti, (5) mengembangkan kompetensi menulis ilmiah dengan meningkatkan kegiatan membaca informasi dari berbagai media dan fenomena yang terjadi dalam kehidupan sehari-hari, (6) mengembangkan profil pribadi dalam jejaring komunikasi ilmiah dengan meningkatkan produktifitas karya tulis ilmiah di jurnal yang terakreditasi nasional dan internasional.

Kemampuan literasi informasi yang belum sepenuhnya dikuasai oleh Informan satu adalah plan, gather dan evaluate. Pada kompetensi plan, informan satu terindikasi tidak menyusun rencana dalam penelusuran sumber sumber informasi karena membebani waktu penulisan karya ilmiah. Informan satu tidak menggunakan strategi khusus, misalnya boolean, dalam menentukan kata kunci. Kata kunci ditentukan berdasarkan kesesuaian dengan tema dan topik karya 
tulis secara trial and error. Pada Kompetensi Gather, informan satu terindikasi menggunakan Sci-Hub untuk mengakses informasi full teks untuk membuka pemblokiran oleh penerbit. Pada kompetensi evaluate, informan satu tidak menggunakan metrik sitasi untuk mengevaluasi sumber informasi, melainkan dengan menilai akreditasi dan indeks jurnal.

Informan dua, adalah peneliti dengan jenjang fungsional tingkat muda di Loka Litbangkes Pangandaran. Informan dua menguasai secara penuh tiga dari tujuh kompetensi literasi informasi dalam penulisan karya ilmiah yaitu identify, scope dan manage. Penguasaan kompetensi manage oleh informan dua meliputi, (1) mengidentifikasi kebutuhan informasi untuk penulisan karya ilmiah berdasarkan kesesuaian topik dan keberadaan lokasi informasi, (2) merumuskan pertanyaan penelitian dengan mengeksplorasi ide dalam topik karya tulis ilmiah. Pertayaan penelitian dijawab oleh kajian literatur untuk memperoleh jawaban secara teoritis sedangkan untuk memperoleh jawaban secara empirik berdasarkan kesimpulan yang sesuai dengan tujuan penelitian, (3) menyusun daftar kebutuhan informasi dalam penulisan karya ilmiah berdasarkan kesesuaian dengan topik.

Penguasaan kompetensi scope oleh informan dua meliputi, (1) menilai relevansi sumber informasi yang digunakan dalam karya tulis ilmiah berdasarkan kesesuaian penggunaan metode penelitian, akreditasi dan indeks jurnal sebagai media publikasi, (2) menentukan gap/kesenjangan dalam perumusan masalah penelitian berdasarkan ketidaksesuaian jawaban yang diperoleh secara teoritis dari pertanyaan penelitian yang dibandingkan dengan realitas situasi dan kondisi di lapangan, (3) memetakan informasi berdasarkan tingkat jumlah sumber informasi yang digunakan dan kerumitan pertanyaan penelitian dalam perumusan masalah, (4) memahami praktik teknik pengumpulan data dengan wawancara, baik terstruktur, semi terstruktur maupun terbuka, observasi dan eksperiman dalam penelitian. Teknik pengumpulan data dalam penulisan karya ilmiah dengan penelusuran informasi baik menggunakan perangkat lunak Mendeley maupun Google Search.

Penguasaan kompetensi manage oleh informan dua meliputi, (1) menggunakan mendeley untuk mengolah sitasi dan bibliografi dalam penulisan karya ilmiah, (2) gaya sitasi yang sering digunakan informan dua adalah Harvard dan Vancouver merupakan gaya selingkung sebagian besar jurnal ilmiah bidang keilmuan penyakit tular vektor, (3) memahami beberapa bentuk plagiarisme dan melakukan upaya pencegahan dengan menghindari copy paste setiap sumber informasi yang digunakan sebagai referensi dalam karya tulis ilmiah, (4) memanfaatkan Mendeley untuk menyimpan sitasi karya tulis ilmiah dan Google Drive sebagai penyimpanan file naskah dan dokumen pekerjaan, (5) memahami etika dalam penulisan karya ilmiah, contohnya pencantuman sitasi sumber asli dan ucapan terima kasih untuk kontributor dalam karya tulis ilmiah. Hak cipta dipahami sebagai hak atas kekayaan intelektual yang harus ditaati dan dihormati melalui ethical clearance dalam setiap penerbitan naskah artikel.

Kemampuan literasi informasi yang belum dikuasai sepenuhnya oleh informan dua adalah plant, gather, evaluate 
dan present. Pada kompetensi plant, informan dua tidak menggunakan strategi khusus menentukan kata kunci. Kata kunci ditentukan berdasarkan kesamaan arti kata dengan topik dan judul karya tulis secara trial and error tanpa teknik boolean dan kosa kata terkendali sehingga hasil pencarian banyak dan tidak fokus. Pada kompetensi gather, informan dua terindikasi menggunakan Sci-Hub untuk mengakses informasi full teks yang diblokir oleh penerbit. Isu kedua yaitu informan dua belum melakukan upaya yang optimal dalam mengikuti dan mengembangkan jejaring komunikasi ilmiah baik di lingkup internal maupun eksternal Loka Litbangkes Pangandaran. Pada kompetensi evaluate, informan dua tidak memeriksa ulang sumber informasi yang digunakan dalam karya tulis ilmiah. Selain itu, informan dua tidak menggunakan metrik sitasi untuk mengevaluasi sumber informasi. Akreditasi media publikasi merupakan dasar penilaian yang digunakan informan dua dalam mengevaluasi sumber informasi. Pada Kompetensi present, informan dua memiliki keterbatasan keterampilan dalam menggunakan bahasa Inggris khususnya untuk penulisan dan presentasi karya ilmiah. Isu kedua yaitu pengembangan profil pribadi dalam jejaring komunikasi ilmiah hanya digunakan untuk persyaratan administratif dalam penelitian, publikasi ilmiah dan evaluasi akreditasi jurnal ilmiah.

Informan tiga adalah peneliti dengan tingkat jenjang fungsional madya di Loka Litbangkes Pangandaran. Informan tiga menguasai secara penuh dua dari tujuh kompetensi literasi informasi dalam penulisan karya ilmiah yaitu identify dan scope. Penguasaan informan tiga terhadap kompetensi identify yaitu, mengidentifikasi kebutuhan informasi untuk penulisan karya ilmiah berdasarkan kesesuaian dengan topik dan keberadaan lokasi sumber informasi, (2) menyusun pertanyaan penelitian berdasarkan perumusan masalah dalam pendahuluan yang meliputi data dukung rangkuman teori, kajian terdahulu dan alasan pemilihan lokasi penelitian. Pertanyaan penelitian dijawab oleh tujuan penelitian yang merupakan pelaksanaan metode penelitian meliputi pengumpulan data, (3) membuat daftar kebutuhan informasi untuk karya tulis berdasarkan kesamaan topik dan tema karya tulis ilmiah.

Penguasaan informan tiga terhadap kompetensi scope yaitu, (1) menilai relevansi informasi berdasarkan akreditasi dan indeks media publikasinya, (2) menentukan gap/kesenjangan dalam permusan masalah berdasarkan perbedaan antara teori dengan kenyataan di lapangan, (3) memetakan informasi berdasarkan kesesuaian topik dengan menempatkan setiap literatur rujukan sesuai kebutuhan setiap bagian karya tulis, (4) memahami praktik teknik pengumpulan data berdasarkan kategori primer (pengumpulan data dalam penelitian), sekunder (data profil dinas terkait) dan tersier (kajian literatur).

Kemampuan literasi informasi yang belum dikuasai sepenuhnya oleh informan tiga adalah plant, gather, evaluate, manage dan present. Pada kompetensi plan, informan tiga tidak merencanakan penelusuran informasi dalam penulisan karya ilmiah karena membuat bingung dalam menentukan tahap awal dan tidak ada alokasi waktu khusus. Isu kedua yaitu teknik boolean dan kosa kata terkendali belum diketahui Iiforman tiga sebagai strategi menentukan kata kunci. Informan 
tiga menentukan kata kunci berdasarkan kesamaan dan kesesuaian arti kata secara trial and error sehingga hasil temuan banyak dan tidak fokus. Pada kompetensi Gather, informan tiga terindikasi tidak melakukan pengelompokan informasi secara hirarkis dan sistematis, menggunakan Sci-Hub untuk mengakses informasi full teks yang diblokir oleh penerbit dan keterbatasan penggunaan media untuk partisipasi jejaring komunikasi ilmiah. Pada kompetensi evaluate, informan tiga tidak melakukan pemeriksaan ulang sumber informasi yang digunakan dalam penulisan karya ilmiah. Informan tiga tidak menggunakan metrik sitasi untuk mengevaluasi sumber informasi melainkan dengan mempertimbangkan aspek akreditasi media publikasinya. Pada kompetensi manage, Informan tiga belum memahami penggunaan perangkat lunak Mendeley khususnya dalam memasukan sitasi ke dalam karya tulis. Isu berikutnya Informan tiga belum memahami penggunaan cloud computing untuk menyimpan informasi dalam jaringan. Pada kompetensi present, informan tiga belum menguasai keterampilan menggunakan bahasa Inggris terutama dalam penulisan artikel ilmiah dan presentasi secara oral sehingga menghambat publikasi karya tulis ilmiahnya ke jurnal internasional.

Faktor pendukung kemampuan literasi informasi peneliti dalam menulis karya ilmiah adalah sebagai berikut, (1) akses internet dan infrastrukturnya telah menjangkau seluruh ruangan di Loka Litbangkes Pangandaran sehingga memudahkan peneliti dalam melakukan penelusuran sumber informasi, (2) kompetensi dan pengalaman yang dimiliki peneliti dalam kegiatan penelitian yang terbukti membantu dalam penguasaan identify dan scope.

Faktor penghambat penguasaan literasi informasi adalah sebagai berikut, (1) kurangnya partisipasi peneliti dalam pelatihan literasi informasi dan belum terselenggaranya pelatihan khusus mengenai literasi informasi oleh Loka Litbangkes misalnya penggunaan teknik Personal Information Management (PIM) dalam mengelompokan informasi, pemanfaatan e-resource Perpustakaan Nasional dan sebagainya, (2) keterbatasan dan tidak berkalanya koleksi pustaka di perpustakaan, (3) penyediaan akses database jurnal internasional oleh Badan Litbangkes sebagai pengampu belum menjangkau peneliti satuan kerja daerah, (4) motivasi peneliti dalam berjejaring komunikasi ilmiah hanya untuk memenuhi ketentuan persyaratan administratif dalam publikasi ilmiah, (5) keterbatasan penguasaan bahasa Inggris menghambat penguasaan literasi informasi khususnya dalam pengembangan kompetensi menulis, publikasi dan presentasi karya ilmiah di tingkat internasional.

$$
\text { Berpikir kritis merupakan }
$$

kemampuan menganalisis, mensintesa, mengevaluasi dan menalar. Ketiga informan memiliki kemampuan berpikir kritis melalui penguasaan aspek-aspek literasi informasi. Indikasinya terbukti dari penguasaan kemampuan merumuskan dan menjawab pertanyaan penelitian, menentukan gap dalam perumusan masalah penelitian, menilai kualitas informasi dan memahami penerapan ringkasan dan sintesis dalam karya tulis ilmiah.

Sikap ilmiah merupakan pengejawantahan cara berpikir yang sesuai dengan metode keilmuan. Ketiga 
informan dinilai mampu bersikap ilmiah melalui penguasaan kemampuan literasi informasi. Indikasinya dari penguasaan kemampuan pemahaman teknik pengumpulan data, menentukan batasan topik karya ilmiah, pengalaman mereviu naskah artikel dan menyajikan data dalam karya ilmiah dengan gaya penulisan yang benar.

Sikap etis merupakan sikap yang berkaitan dengan prinsip-prinsip moralitas, benar dan salah dalam melakukan suatu hal. Ketiga Informan terindikasi memiliki sikap tidak etis dalam penguasaan literasi informasi. Isu sikap tidak etis tersebut terindikasi dari mengakses informasi secara full teks melalui Sci-Hub untuk membuka pemblokiran penerbit terhadap akses database jurnal berbayar. Tindakan tersebut merupakan penelusuran informasi yang dilakukan secara tidak etis karena melanggar aspek legalitas dan hak kekayaan intelektual konten sumber informasi.

\section{SIMPULAN}

Berdasarkan hasil penelitian disimpulkan bahwa tujuh kemampuan literasi informasi SCONUL Seven Pillars Information Literacy Research Lens belum seluruhnya dikuasai oleh peneliti. Kompetensi yang belum sepenuhnya dikuasai peneliti tingkat pertama adalah merencanakan penelusuran informasi, strategi menentukan kata kunci dalam penelusuran informasi, mengakses informasi secara full teks, dan pemahaman metrik sitasi dalam mengevaluasi sumber informasi. Kemampuan literasi informasi yang belum sepenuhnya dikuasai oleh peneliti tingkat muda adalah strategi menentukan kata kunci dalam penelusuran informasi, mengakses informasi secara full teks, pemeriksaan ulang sumber informasi, pemahaman metrik sitasi untuk mengevaluasi sumber informasi, partisipasi pengembangan profil dalam jejaring komunikasi ilmiah dan pengembangan kompetensi menulis ilmiah. Kemampuan literasi informasi yang belum sepenuhnya dikuasai oleh peneliti tingkat madya yaitu merencanakan penelusuran informasi, strategi menentukan kata kunci dalam penelusuran informasi, mengelompokan informasi, mengakses informasi secara full teks, memeriksa ulang sumber informasi dalam karya tulis ilmiah, pemahaman metrik sitasi untuk mengevaluasi sumber informasi, penggunaan perangkat lunak pengolah bibliografi, pemanfaatan penyimpanan informasi dalam jaringan dan mengikuti, pengembangan jejaring komunikasi ilmiah dan kompetensi dalam menulis ilmiah. Penguasaan kompetensi literasi informasi dihambat oleh kurangnya partisipasi peneliti dalam pelatihan dan workshop literasi informasi, keterbatasan dan ketidakberkalaan pengadaan koleksi pustaka di perpustakakan, tidak tersedianya akses database jurnal internasional, kurangnya motivasi berjejaring komunikasi ilmiah yang hanya untuk persyaratan administratif publikasi ilmiah dan keterampilan bahasa Inggris yang masih terbatas. Kompetensi literasi informasi yang sudah dikuasai sepenuhnya oleh peneliti tingkat pertama, muda dan madya adalah identify dan scope. Kompetensi identify terdiri dari kemampuan mengidentifikasi kebutuhan informasi dalam penulisan karya ilmiah, merumuskan dan menjawab pertanyaan penelitian serta membuat daftar kebutuhan informasi dalam penulisan karya ilmiah. Kompetensi scope terdiri 
dari mengetahui relevansi sumber informasi, menentukan gap/kesenjangan dalam penulisan karya ilmiah, pemetaan sumber informasi dan pemahaman teknik pengumpulan data. Penguasaan kedua kompetensi tersebut di dukung oleh pengetahuan dan pengalaman dalam tugas pokok dan fungsi utama yang sudah dimiliki oleh setiap peneliti di Loka Litbangkes Pangandaran, ketersediaan akses internet dan infrastruktur pendukungnya di Loka Litbangkes Pangandaran. Faktor pendukung berikutnya adalah kompetensi dan pengalaman peneliti baik dalam kegiatan penelitian maupun dalam penulisan dan publikasi karya ilmiah. Untuk meningkatkan kemampuan literasi informasi, peneliti disarankan aktif berpartisipasi dalam pelatihan Bahasa Inggris untuk publikasi dan presentasi ilmiah, workshop pemanfaatan e-resource dan cloud storage secara etis dan mengembangkan jejaring komunikasi ilmiah khususnya kolaborasi dalam penelitian dan publikasi ilmiah. Loka Litbangkes Pangandaran sebagai institusi diharapkan meningkatkan kualitas layanan informasi perpustakaan dan menjalin kerja sama dengan Badan Litbangkes dalam menyediakan database jurnal terakreditasi dan terindeks internasional bagi peneliti.

\section{DAFTAR PUSTAKA}

Bent, M., \& Stubbings, R. (2011). The SCONUL seven pillars of information literacy a research lens for higher education. USA: SCONUL Working Group on Information Literacy. Retrieved from https://www.sconul.ac.uk/sites/def ault/files/documents/coremodel.pdf

Bordonaro, K. (2008). Exploring the connections between information literacy and writing for international students. Journal of Information Literacy, 2(2), 1-17. Retrieved from http://sci-

hub.tw/https://doi.org/10.11645/2.2 .67

Chaudhry, A. S., \& Al-Mahmud, S. (2015). Information literacy at work: A study on information management behaviour of Kuwaiti engineers. The Electronic Library, 33(4), 760-772. https://doi.org/https://doi.org/10.1 108/EL-04-2014-0063

Cheuk, B. (2008). Delivering business value through information literacy in the workplace. Libri, 58(3), 137-143.

Detlor, B., Julien, H., Willson, R., Serenko, A., \& Lavallee, M. (2011). Learning outcomes of information literacy instruction at business schools. Journal of the American Society for Information Science and Technology, 62(3), 572-585.

Hasugian, J. (2008). Urgensi literasi informasi dalam kurikulum berbasis kompetensi di perguruan tinggi. Pustaha: Jurnal Studi Perpustakaan dan Informasi, 4(2), 34-44.

Ibrahim. (2015). Metodologi penelitian kualitatif panduan penelitian kualitatif beserta contoh proposal. Bandung: Alfabeta. Retrieved from http://opac.lib.ugm.ac.id/index.php? mod=book_detail\&sub=BookDetail\&a $\mathrm{ct}=$ view\&typ $=$ htmlext\&buku_id=7455 50\&unit_id=1900

LIPI. (2012). Peraturan Kepala LIPI nomor 04/E/2012 tentang pedoman karya tulis ilmiah. Bogor: Pusbindiklat PenelitiLIPI.

Menteri Pendayagunaan Aparatur Negara. Keputusan Menteri Pendayagunaan Aparatur Negara nomor: KEP/128/M.PAN/2004 tentang jabatan fungsional peneliti dan angka 
kreditnya (2004). Indonesia: Kementerian Pendayagunaan Aparatur Negara. Retrieved from http:// pusbindiklat.lipi.go.id/wpcontent/uploads/KEPMENPAN-128M.PAN-9-2004.pdf

Rapchak, M., \& Cipri, A. (2015). Standing alone no more: Linking research to a writing course in a learning community. Portal: Libraries and the Academy, 15(4), 661-675. Retrieved from

https:// muse.jhu.edu/article/595060

Shao, X., \&, \& Purpur, G. (2016). Effects of information literacy skills on student writing and course performance. The Journal of Academic Librarianship, 42(6), 670-678. https://doi.org/10.1016/j.acalib.2016. 08.006

Soleymani, M. R. (2014). Investigating the relationship between information literacy and academic performance among students. Journal of Education and Health Promotion, 3(1), 95. https://doi.org/10.4103/22779531.139677

Sukaesih, \& Rohman, A. S. (2013). Literasi Informasi Pustakawan: Studi Kasus di Univeristas Padjadjaran. Jurnal Kajian Informasi \& Perpustakaan, 1(1), 71.

White-Farnham, J., \&, \& Gardner, C. C. (2014). Crowdsourcing the curriculum: Information literacy instruction in first-year writing. Reference Services Review, 42(2), 277292. https:// doi.org/10.1108/RSR-092013-0046

Wicaksono, A. (2016). Profil literasi informasi pustakawan Indonesia. Berkala Ilmu Perpustakaan dan Informasi, 12(1), 1-9.

Yusup, P. M., \&, \& Saepudin, E. (2017). Praktik literasi informasi dalam proses pembelajaran sepanjang hayat. Jurnal Kajian Informasi \& Perpustakaan, 5(1), 91. Retrieved from http://jurnal.unpad.ac.id/jkip/article /view/11387/6030 